\title{
Molecular differentiation of Turkish and Common hazels (Corylus colurna L. and Corylus avellana L.) using multiplexed nuclear microsatellite markers
}

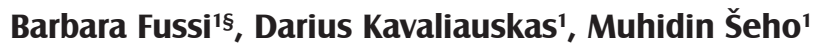

Fussi B., Kavaliauskas D., Šeho M.. Molecular differentiation of Turkish and Common hazels (Corylus colurna L. and Corylus avellana L.) using multiplexed nuclear microsatellite markers. Ann. For. Res. 62(2): 173-182.

Abstract. Corylus colurna is considered as important tree species under climate change for dry and warm conditions in Central Europe and was overused because of its valuable wood. Therefore Turkish hazel is now present only in small isolated populations and is protected under IUCN. Genetic conservation of this tree species plays a key role in future sustainable forest development. Turkish hazel co-occurs with Common hazel (C. avellana) in its whole distribution area and may form hybrids. To differentiate between the pure species and their hybrids, cross-species amplifying markers are required. In this study we have evaluated existing simple sequence repeat (SSR) markers using altogether 128 samples of $C$. avellana and C. colurna. Fifteen nuclear SSRs have generated easy to-score alleles in the two species and 13 of them were highly polymorphic. For all 15 markers the mean allele number, average observed heterozygosity, genetic diversity and polymorphism information index were high. The two most polymorphic SSRs were L1.10 and CaT-B501 with 19 and 16 alleles, respectively. Structure analysis proved the differentiation of the two species $C$. avellana and C. colurna. No hybridization was detected in the analysed populations. Results also indicated that $C$. colurna from Balkan Peninsula and Asia Minor belong to separate groups. Our study presents highly polymorphic, easy to score, ready to use SSR-multiplexes, which can be applied in population genetics and gene conservation studies.

Keywords: SSR, multiplex PCR, polymorphism, species differentiation, molecular markers, hazelnut

Authors. ${ }^{1}$ Bavarian Office for Forest Genetics (AWG), Forstamtsplatz 1, 83317 Teisendorf, Germany.

§Corresponding author: Barbara Fussi (barbara.fussi@awg.bayern.de)

Manuscript received November 21, 2018; revised December 20, 2019; accepted December 28, 2019; online first December 31, 2019.

\section{Introduction}

Climate change affects all forest ecosystems and goods that forests provide. A suitable strat- egy to increase the stability of forest stands is given through establishing mixed forests. By supplementing the existing spectrum of tree species in Central Europe, the risk can be min- 
imized. Therefore we examine tree species from the Mediterranean region for its drought resistance and their suitability to be cultivated in Germany. Turkish hazel is considered as a valuable tree species under climate change with high adaption potential to drought and frost (Šeho et al. 2019). Turkish hazel ( $C$. colurna L.) and Common hazel (C. avellana L.) belong to the family of birch plants (Betulace$a e$ ), with the subfamily Corylaceae which has four genera. The genus Corylus has 12 species distributed in the temperate zones of Eurasia and North America (Mitchell 1979, Fitschen 1994, Alteheld 1996, Erdogan \& Mehlenbacher 2000a). The genus is diploid $(2 n=2 x=22)$, and contains monoecious and wind-pollinated shrubs and trees (Bassil et al. 2013). Within section Corylus, three subsections are traditionally recognized. C. colurna $L$. and $C$. avellana belong to different subsections (Subsection Colurnae and Phyllochlamys, respectively) (Erdogan \& Mehlenbacher 2000).

C. colurna is naturally distributed on the Balkan Peninsula, Asia Minor, the Caucasus and Afghanistan (Temel et al. 2017, Šeho \& Huber 2018, Šeho et al. 2019). By supplementing the existing spectrum of broad-leaved tree species with Turkish hazel in Central Europe, the risks raised by changing climate can be minimized. To recommend suitable provenances for Central Europe research on genetic and phenotypic diversity between and within C. colurna populations is necessary. Turkish hazel can reach an age of 400 years, DBH of $60 \mathrm{~cm}$ (in some cases up to $170 \mathrm{~cm}$ ) and height of $30 \mathrm{~m}$ depending on the growth conditions (Alexandrov 1995, Alteheld 1996, Schmidt 2003, Richter 2013, Šeho \& Huber 2018, Šeho et al. 2019). In contrast, Common hazel is growing as a shrub. These two hazel species have different morphology of leaves and fruits. Turkish hazel has 17-20 mm long nuts ripening in 5 to 6 pods surrounded by deeply divided lobes. Nuts are smaller than those of $C$. avellana. Leaves of Common hazel are slightly smaller and lighter green and the bark is less grey than that of Turkish hazel. Between these 174 two hazelnuts (C. colurna L. and C. avellana L.) hybrids can be formed rarely (Alexandrov 1995; Erdogan \& Mehlenbacher 2000, Jahn 1930). Jahn (1930) described some differences between three possible hybrids between $C$. colurna and $C$. avellana in botanical gardens in Hann. Münden, Göttingen and Jena (Germany). However, he was not absolutely certain that these trees are natural hybrids.

In Germany, Common hazel is intensively traded and planted, and thus is of central interest from a nature conservancy point of view. Leinemann et al. (2013) studied Common hazel using chloroplast markers (cpSSRs), isozymes and AFLPs with the aim to assess the within and between population variation of 20 natural populations from Central Europe. Significant differences between populations were found. Like other plant species, the distribution of Common hazel is strongly affected by postglacial recolonization (Huntley \& Birks 1983, Huntley 1990, Palmé \& Vendramin 2002). A clear geographical structure was found on the European scale separating Italy and the Balkans from the rest of Europe (Palmé \& Vendramin 2002). Together with pollen data the possible origin of Central European Common hazel would be France expanding into most of Europe and a local expansion in Italy and the Balkans. C. avellana and C. colurna share one haplotype indicating common ancestry or hybridization between the two species. For $C$. colurna there is a knowledge gap about potential refugia or recolonization routes after the last glacial maximum.

For further cultivation of Turkish hazel in Central Europe it is important that the invasiveness of this tree species through hybridization will be evaluated. Artificial crossing experiments between $C$. colurna x $C$. avellana L. yielded in the formation of few fruit clusters with $C$. avellana as the male parent, but failed to set full seeds. The reciprocal cross, $C$. avellana x $C$. colurna, set very few nuts only in one of three breeding years (Erdogan \& Mehlenbacher 2000). Percentage of seed germination was higher when $C$. avellana was pollen 
donor and C. colurna female crossing partner. Seedling vigor, recorded as stem diameter, was highly variable among the interspecific crosses. In general, the cultivated hazelnut $C$. avellana, and the tree hazel species $C$. colurna and $C$. chinensis yielded very vigorous interspecific hybrid seedlings (Erdogan \& Mehlenbacher 2000). However, the crossability of $C$. colurna and $C$. avellana was under discussion in the 1960ies (Kasapligil 1963, 1964). Gellatly (1966) reported some hybrids and named them trazels, derived from open-pollination of C. colurna trees, morphologically indicating true hybrids (varieties called 'Morrisoka' and 'Faroka'). Erdogan \& Mehlenbacher (2000) indicate that crossability between these two species is complicated but possible. In their study C. colurna x C. avellana resulted in cluster set every year, but with high proportion of empty seeds and only few viable seedlings. Breeders need to perform large numbers of pollinations to obtain a few hybrid seedlings (Erdogan \& Mehlenbacher 2000). Bassil et al. (2013) reported about hybridization supported by nuclear and chloroplast microsatellite data, where C. colurna - C. avellana hybrids formed a distinct group, while accessions of $C$. colurna were placed in one cluster with two $C$. avellana cultivars from southern Italy ('Tonda Bianca' and 'Tonda Rossa').

Microsatellites or simple sequence repeats (SSRs) are short, tandemly repeated DNA sequences (Oliveira et al. 2006 and references therein, Wang et al. 2009). They have become valuable molecular tools for fingerprinting accessions, assessment of genetic diversity in collections and linkage mapping, due to their abundance, high degree of polymorphism, co-dominance, suitability for automation and transferability across experiments and among labs (Barbara et al. 2007, Ellis \& Burke 2007, Wang et al. 2009).

For studying related species and their hybrids, markers that work in both species are needed. While development of new SSRs is costly and time-consuming the transferability of nuclear microsatellite loci across species/ taxa or genera depends on various factors such as species generation time, type of breeding system, genome size, etc. (Barbara et al. 2007, Ellis \& Burke 2007). Lower success rate of SSR transferability was observed in selfing species and species with high genome size such as tree species and has therefor to be evaluated case-by-case (Barbara et al. 2007). Compared to "anonymous" SSRs EST-SSRs are easier to be transferred between species especially among plants (Ellis \& Burke 2007 and references therein). The transferability of SSR markers allows their usage in related species for fingerprinting, mapping, and marker-assisted breeding (Ellis \& Burke 2007). Examples include the high transferability rate of SSRs in several tree species from apple (Malus domestica) to European pear (Pyrus communis) (Pierantoni et al. 2004), from peach (Prunus persica) to related Prunus species (Cipriani et al. 1999), and within oaks (from Quercus petraea to Quercus robur, Steinkellner et al. 1997).

The goal of this study was to establish high quality sets of molecular markers (i.e. ready to use multiplexes of nSSRs) for both species C. colurna and C. avellana and use them to investigate species differentiation and genetic diversity in natural populations. Therefor we used markers developed for C. avellana (Boccacci et al. 2005, Gürcan et al. 2010, Gürcan \& Mehlenbacher 2010b) and Betula pendula (Kulju et al. 2004).

\section{Material and methods}

\section{Plant material}

Three populations were selected for genetic analysis from their native range: two populations of C. colurna, one in Turkey (Bolu) and one in Bosnia and Herzegovina (Rogatica), and one population of $C$. avellana from Germany (Laubau, Bavaria) (Table 1). In order 
Table 1 Plant material and description of stands

\begin{tabular}{llllll}
\hline Tree species & Location & Region & Source & Number of samples Coordinates \\
\hline C. avellana & Laubau, Germany & Central Europe & native & \multirow{2}{*}{40} & $\begin{array}{l}47^{\circ} 43^{\prime} \mathrm{N} \\
12^{\circ} 38^{\prime} \mathrm{E}\end{array}$ \\
\hline C. colurna & Rogatica, Bosnia & Southeastern Europe? & native & \multirow{2}{*}{33} & $43^{\circ} 44^{\prime} \mathrm{N}$ \\
& and Herzegovina & Asia & native & \multirow{2}{*}{55} & $48^{\circ} 57^{\prime} \mathrm{E}$ \\
\hline C. colurna & Bolu, Turkey & \begin{tabular}{l} 
minor \\
\hline
\end{tabular} & & & $30^{\circ} 48^{\prime} \mathrm{N}$ \\
\hline
\end{tabular}

to test for phylogeografic influence on marker performance the two $C$. colurna populations were chosen to represent the two major natural regions of the species. The $C$. avellana population from Central Europe was chosen in order to obtain C. avellana specific alleles from the tested marker set. By this procedure species specific alleles can be identified and used for species and hybrid detection in future studies. A representative sampling procedure was chosen for each stand regarding density and number of trees. In order to evaluate the markers for their degree of polymorphism between and within species and genetic diversity parameters within populations leaf material was derived from at least 30 trees per population.

\section{DNA isolation}

Total nuclear DNA was extracted from a standardized quantity of plant tissue (four leaf discs, $\varnothing=6 \mathrm{~mm}$ ). Plant material was dried in silica gel and disrupted using a Mixer Mill MM400 (Retsch, Germany). A 5 mm tungsten bead was added in each $2 \mathrm{ml}$ Eppendorf tube and followed by 4-min disruption at $30 \mathrm{~Hz}$. DNA was isolated following Doyle \& Doyle (1990). DNA extracts were fluorometrically quantified (Gene Quant Pro, Amersham Bioscience) and adjusted to $20 \mathrm{ng} / \mu \mathrm{l}$.

\section{Multiplex PCR optimization}

Kit1 comprised four SSR loci originating from Betula pendula Roth (Kulju et al. 2004), Kit2 contained six SSR loci developed by Boccacci et al. (2005) and Gürcan et al. (2010), and Kit3 contained five loci developed by Gürcan et al. 176
(2010) and Gürcan \& Mehlenbacher (2010b).

None of these markers had been multiplexed before. Criteria for SSR inclusion into the multiplexes were the number of alleles $(>3)$, lack of evidence for null alleles $(r<0.05$, as defined in Brookfield 1996), good amplification success and easy to score pattern in both species. Altogether 15 primer pairs were tested for amplification in each of the two species. Amplification success was indicated by the presence of a fragment peak in the capillary electrophoresis. Optimization was needed for concentration of the primers in the final PCR mix.

Altogether 128 individuals were genotyped at 15 highly polymorphic nuclear microsatellite loci combined into three multiplex PCRs (Table 2). Primer sequences and repeat motif with literature of original publication, fluorescent labels of primers, final concentrations in final PCRs and annealing temperature are given. Reverse primers from each primer pair were labelled with fluorescent dyes Cy5, IRD700 (both Biomers) and DY751 (Metabion).

PCR amplification was performed with Type-it Microsatellite PCR kit (Qiagen, $\mathrm{GmbH}$, Hilden, Germany) in the total volume of $15 \mu \mathrm{l}$ solution: $1 \mu \mathrm{l}$ of $20 \mathrm{ng} / \mu \mathrm{l}$ genomic DNA, $7.5 \mu$ of $2 \mathrm{X}$ Qiagen Multiplex PCR Master mix, $5 \mu$ l of RNase free water and 1.5 $\mu l$ of Primer Mix respectively.

The targeted fragments were amplified with a thermocycler (Biometra, Analytic Jena): by using the following cycling conditions: Initial denaturation $\left(95^{\circ} \mathrm{C}\right.$ for $\left.15 \mathrm{~min}\right), 26$ amplification cycles $\left(94^{\circ} \mathrm{C}\right.$ for $30 \mathrm{~s}$, Tm according to multiplex for $90 \mathrm{~s}, 72^{\circ} \mathrm{C}$ for $30 \mathrm{~s}$ ), 1 final elon- 


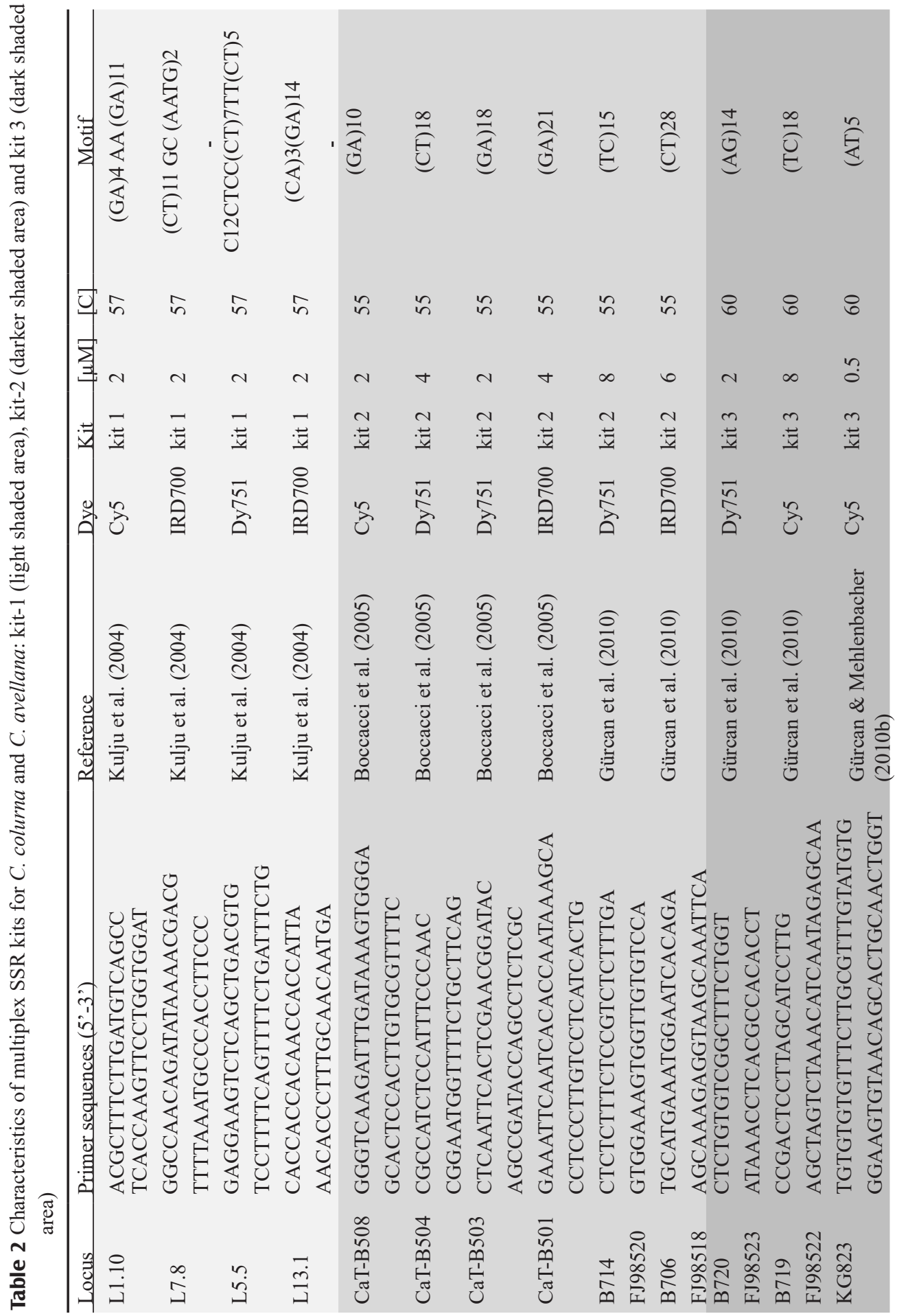




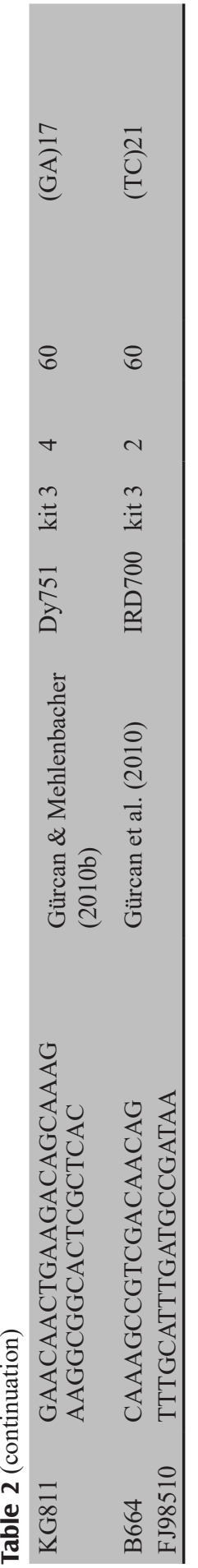

gation step $\left(60^{\circ} \mathrm{C}\right.$ for $\left.30 \mathrm{~min}\right)$. PCR amplification products were separated via capillary electrophoresis using 8-capillary DNA Analyzer automated sequencer [GenomeLab ${ }^{\mathrm{TM}}$ GeXP Genetic Analysis System (GeXP), AB Sciex]. Sizing of fragments was performed manually with Fragment Analyzer tool implemented in GenomeLab Software.

\section{Characterization of polymorphic markers}

Diversity values of SSRs ( $n A$ - total number of alleles, $\mathrm{A}$ - mean number of alleles per population, $H_{o}$ - observed heterozygosity, $H_{e}$ - expected heterozygosity, $F$ - fixation index; $F_{s t}$ - differentiation between subpopulations) were calculated using GenAlEx 6.5 (Peakall \& Smouse 2012). The frequency of null alleles ( $r$ ) was estimated as $r=(\mathrm{He}-\mathrm{Ho}) /$ $(1+\mathrm{He})$ (Brookfield 1996) in a spreadsheet and also tested with MICRO-CHECKER 2.2.0.3 (Van Oosterhout et al. 2004). The PIC value for each locus was estimated using Cervus (Kalinowski et al. 2007).

\section{Genetic differentiation between populations}

The Bayesian clustering algorithm implemented in the software program STRUCTURE 2.3.4 (Pritchard et al. 2000) was used to infer population structure and assign individuals to modelled populations based on their SSR genotypes. The most likely number of clusters was assessed using the empirical statistic $\Delta K$ calculated by STRUCTURE HARVESTER (Evanno et al. 2005; Earl \& von Holdt 2012). The admix- ture model and correlated allele frequencies between clusters with default parameter settings were used, with $K$ varying from one to six. The burn-in length was set to 200,000 with runs of 100,000 steps, and each run was replicated ten times.

\section{Results}

\section{SSR amplification and polymorphism}

The variation of each nuclear microsatellite locus is given in Table 3. Fragment size ranges are given for each locus. Total number of alleles range from 6 (B714) to 19 (L1.10). The lowest mean number of alleles per population was detected for locus B714 (2.7), the highest in B719 (9.7). Observed heterozygosity was lowest in B714 (0.418) and highest in CaT-B501 (0.831). Expected heterozygosity was between 0.391 (B714) and 0.789 (CaT-B501). For one locus B719 in population Rogatica presence of null-alleles was detected by MICRO-CHECKER 2.2.0.3 (Van Oosterhout et al. 2004). No evidence of null-alleles was shown for the other two populations, therefore all 15 markers were kept for further analysis. R-value for the marker B719 was higher than 0.05 , but it was kept because of its high variability. F-values ranged from -0.09 (CaT-B504) to 0.161 (B719). The mean F-value across all loci and populations was 0.001 . PIC was larger than 0.5 for all marker loci, meaning all are highly polymorphic, according to Botstein et al. (1980). Six loci had a PIC value above 0.8. Combined with high 
Table 3 Genetic variability of 15 nuclear microsatellites based on 40 samples of Corylus avellana from southern Germany and 88 samples from C. colurna from Turkey and Bosnia and Herzegovina

\begin{tabular}{llclllllll}
\hline Locus & Size & $n A$ & $A$ & $H o$ & $H e$ & $F$ & $r$ & $P I C$ & $F s t$ \\
\hline L1.10 & $171-273$ & $\mathbf{1 9}$ & 8.0 & 0.652 & 0.688 & 0.036 & 0.021 & 0.84 & 0.22 \\
L7.8 & $258-264$ & 11 & 7.7 & 0.781 & 0.771 & -0.008 & -0.006 & 0.80 & $\mathbf{0 . 0 8}$ \\
L5.5 & $112-128$ & 8 & 5.3 & 0.441 & 0.453 & 0.062 & 0.008 & 0.69 & 0.38 \\
L13.1 & $100-112$ & 7 & 4.0 & 0.544 & 0.528 & -0.029 & -0.010 & $\mathbf{0 . 5 4}$ & 0.11 \\
CaT-B508 & $142-172$ & 15 & 9.3 & 0.695 & 0.742 & 0.063 & 0.027 & 0.78 & 0.09 \\
CaT-B504 & $166-184$ & 9 & 6.3 & 0.800 & 0.734 & $\mathbf{- 0 . 0 9 0}$ & $\mathbf{- 0 . 0 3 8}$ & 0.81 & 0.12 \\
CaT-B503 & $115-153$ & 13 & 7.3 & 0.692 & 0.706 & 0.034 & 0.008 & 0.79 & 0.15 \\
CaT-B501 & $104-136$ & 16 & 7.3 & $\mathbf{0 . 8 3 1}$ & $\mathbf{0 . 7 8 9}$ & -0.054 & -0.024 & $\mathbf{0 . 8 7}$ & 0.11 \\
B714 & $232-244$ & $\mathbf{6}$ & $\mathbf{2 . 7}$ & $\mathbf{0 . 4 1 8}$ & $\mathbf{0 . 3 9 1}$ & -0.034 & -0.020 & 0.67 & $\mathbf{0 . 4 4}$ \\
B706 & $170-202$ & 11 & 6.3 & 0.659 & 0.640 & -0.032 & -0.012 & 0.75 & 0.18 \\
B720 & $160-174$ & 8 & 5.3 & 0.608 & 0.636 & 0.050 & 0.017 & 0.74 & 0.17 \\
B719 & $278-318$ & 14 & $\mathbf{9 . 7}$ & 0.637 & 0.774 & $\mathbf{0 . 1 6 1}$ & $\mathbf{0 . 0 7 7}$ & 0.86 & 0.12 \\
KG823 & $151-183$ & 11 & 5.0 & 0.719 & 0.675 & -0.063 & -0.026 & 0.81 & 0.17 \\
KG811 & $240-280$ & 12 & 7.3 & 0.710 & 0.684 & -0.036 & -0.016 & 0.73 & 0.12 \\
B664 & $188-216$ & 13 & 5.3 & 0.620 & 0.587 & -0.052 & -0.021 & 0.76 & 0.25 \\
\hline
\end{tabular}

number of alleles, those markers are the most informative ones. Most discriminative power between the species has locus B714 with $F_{s t}$ of 0.44 followed by L5.5 $\left(F_{s t}=0.38\right)$. Locus L7.8 has the lowest discrimination power with $F_{s t}$ of 0.08 . Overall, the allele size ranges for each locus did not vary much across the two species, except for locus L1.10. The allele size for $C$. avellana ranged from 171-191 bp and for $C$. colurna it ranged from $217-273 \mathrm{bp}$.

\section{Species and population differentiation}

Based on STRUCTURE results a clear separation of the two Corylus species has been detected. $\mathrm{K}=2$ was defined as the most likely number of clusters (Appendix 1). Figure 1 displays the separation of the $C$. avellana population (green) and the two C. colurna populations (red). The second most likely clustering was at $\mathrm{K}=3$ pointing to the different gene pools within Turkish hazel (Figure 2).

\section{Discussion}

The development and optimization of micro- satellites is an expensive and time-consuming process. Therefore the possibility for transferring SSRs to related species is of potential interest, particularly for C. colurna where only a limited number of SSRs were tested so far. Accordingly, the SSRs were tested on two populations of $C$. colurna and one $C$. avellana population. The populations were chosen from important geographic regions of $C$. avellana (Central Europe) and C. colurna (Balkan and Asia Minor). Cross-amplification was tested on more than 30 individuals from each population. The transferability of microsatellite loci was evaluated for the two species. All tested primer pairs amplified DNA fragments in those two species, regardless of the origin of the sample. A locus was considered conserved when one or two high peaks of the expected size were obtained from PCR. Fifteen microsatellite loci produced amplified products of the expected length in the two species tested. Therefor transferability rates for the used SSRs were $100 \%$. Such a high cross-amplification of hazelnut microsatellite markers agrees with previous reports in Corylus (74-100 \% in Bassil et al. 2013, Bassil et al. 2005, Boccacci et al. 2005, Gürcan \& Mehlenbacher 2010a). 


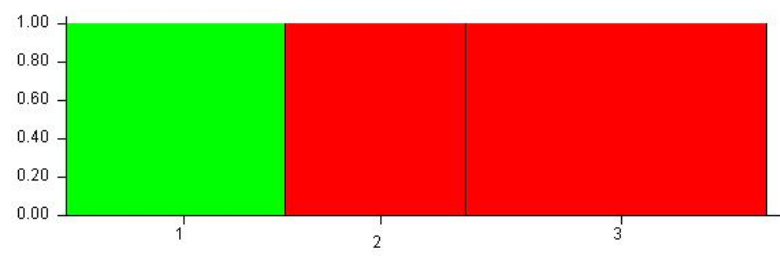

Figure 1 The plot of the inferred Structure clusters $(K=2)$. First cluster (green) C. avellana population (1) and second cluster (red) C. colurna populations (Bolu 2 and Rogatica - 3)

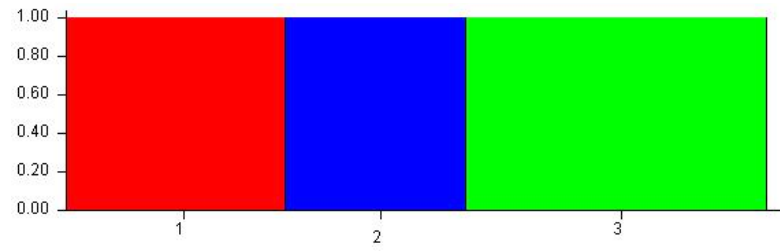

Figure 2 The plot of the inferred Structure clusters $(K=3)$. First cluster (red) C. avellana population (1), second cluster (blue) C. colurna population Bolu (2) and third cluster (green) C. colurna population Rogatica (3).

For other species (e.g. E. globulus) EST-SSRs transferability rates varied between $70-78 \%$ for six related Eucalyptus species (Acuña et al. 2012).

Bassil et al. (2013) reports values based on seven trinucleotide SSRs, the average heterozygosity was moderate at 0.63 while allele number, genetic diversity and PIC were high (means of $11.71,0.79$ and 0.76 , respectively). Out of the $14 \mathrm{nSSRs}$ used by Bassil et al. (2013) in 13 C. colurna accessions seven of the loci had PIC below 0.4 and/or observed heterozygosity close to zero (CaC-C003, CaC-C005, CaC-C036, CaC-C111, CaC-C112, CaC-C119, CaT-C501), therefor we decided to test other loci. Ten out of our 15 tested loci amplified more than ten alleles. The two most polymorphic markers were $\mathrm{B} 719(\mathrm{~A}=9.7)$ and $\mathrm{CaT}$ B508 $(A=9.3)$. The average heterozygosity of the 15 loci was at 0.65 and average PIC was at 0.79 . Thereby a set of 15 robust SSR markers was created based on low estimated percentage of null allele frequencies, high PIC values and high cross species transferability.

The SSRs also proof to be useful for species identification and for the detection of potential hybrids in the respective populations. Bassil et al. (2013) reported on the phylogenetic organization of 11 species and 44 hybrids. Several times artificial crossing of $C$. avellana and $C$. colurna were reported, while crosses involving $C$. avellana as the male parents were more successful (Erdogan \& Mehlenbacher 2000). Jahn (1930) described three trees in botanical gardens as natural hybrids. One of those trees was situated in Göttingen with only few seeds observed, which were not germinating. Another tree was placed in Hann. Münden and was defined as a natural hybrid because of morphological characteristics. Backcrossed progenies of this tree were observed due to $C$. avellana in the vicinity of the hybrid serving as pollen donor. This is the only report on natural hybrids found in the literature. No hybrids were found within the two C. colurna populations analysed in this study. Furthermore also a clear separation of populations of $C$. colurna from Balkan and Turkey was found (Šeho et al. 2017) and point to differentiation of genepools within Turkish hazel.

Altogether the newly combined marker sets can be used to genetically characterize the structure and diversity of natural forest populations of C. colurna. They can help to identify glacial refugia and to study hybridization in mixed stands of the two species. Combined with phenotypic characterization of forest stands the results of this study build the base of provenance research under climate change. Genetic data based on the developed markers will assist in provenance recommendation and proof of identiy of forest reproductive material derived from characterized stands. 


\section{Acknowledgements}

The study was funded by the Federal Ministry for Food and Agriculture through the Fachagentur Nachwachsende Rohstoffe (FNR-Support code 22018914). We are also indebted to landowners for allowing access to their property and to Prof. Sezgin Ayan, Andreas Zaiser and Milos Mirkovic for assistance with sampling. We thank Susanne Nowak and Roswitha Jenner for technical assistance in lab work and scoring, Gerhard Huber for valuable discussion.

\section{References}

Acuña C.V., Fernandez P., Villalba P.V., García M.N., Hopp H.E., Marcucci Poltri S.N., 2012. Discovery, validation, and in silico functional characterization of EST-SSR markers in Eucalyptus globulus. Tree Genetics \& Genomes 8: 289-301. DOI: 10.1007/s11295-0110440-0

Alexandrov A.H., 1995. Corylus colurna. In: Schütt P., Schuck J., Aas G., Lang U. (eds.), Enzyklopädie der Holzgewächse [Encyclopedia of the woody plants. Manual and atlas of the woody plants]. Handbuch und Atlas der Holzgewächse. 2. Erg.Lfg. Landsberg am Lech: ecomed-Verlag. Band III-2.

Alteheld R., 1996. Die Turkish hazel: Monographie einer Baumart [Turkish hazel: Monography of a tree species]. In: Baumkunde. Band 1. Eching: IHW-Verlag, pp. 3975.

Barbara T., Palma-Silva C., Paggi G.M., Bered F., Fay M.F., Lexer C., 2007. Cross-species transfer of nuclear microsatellite markers: potential and limitations. Molecular Ecology 16: 3759-3767. DOI: 10.1111/j.1365294X.2007.03439.x

Bassil N.V., Botta R., Mehlenbacher S.A., 2005. Microsatellite markers in hazelnut: isolation, characterization and crossspecies amplification. Journal of the American Society for Horticultural Science 130:543-549. DOI: 10.21273/JASHS.130.4.543

Bassil N., Boccacci P., Botta R., Postmann J., Mehlenbacher S., 2013. Nuclear and chloroplast microsatellite markers to assess genetic diversity and evolution in hazelnut species, hybrids and cultivars. Genetic Resources and Crop Evolution 60: 543. DOI: 10.1007/s10722012-9857-z

Boccacci P., Akkak A., Bassil N.V., Mehlenbacher S.A., Botta R., 2005. Characterization and evaluation of microsatellite loci in European hazelnut (Corylus avellana L.) and their transferability to other Corylus species. Molecular Ecology Notes 5: 934-937. DOI: 10.1111/j.1471-8286.2005.01121.x
Botstein D., White R L., Skolnick M H., Davies R W., 1980. Construction of a genetic linkage map in man using restriction fragment length polymorphisms. American Journal of Human Genetics 32: 314-331.

Brookfield J.F.Y., 1996. A simple new method for estimating null allele frequency from heterozygote deficiency. Molecular Ecology 5: 453-455. DOI: 10.1111/j.1365294X.1996.tb00336.x

Cipriani G., Lot G., Huang W.G., Marrazzo M.T., Peterlunger E., Testolin R., 1999. AC/GT and AG/CT microsatellite repeats in peach [Prunus persica (L.) Batsch]: isolation, characterisation and cross-species amplification in Prunus. Theoretical and Applied Genetics 99: 65. DOI: $10.1007 / \mathrm{s} 001220051209$

Doyle J.J., Doyle L.J., 1990. Isolation of plant DNA from fresh tissue. Focus 12: 13-15. DOI: $10.2307 / 2419362$

Earl D.A., vonHoldt B.M., 2012. STRUCTURE HARVESTER: a website and program for visualizing STRUCTURE output and implementing the Evanno method. Conservation Genetics Resources 4(2): 359361. DOI: 10.1007/s12686-011-9548-7

Ellis J.R., Burke J.M., 2007. EST-SSRs as a resource for population genetic analyses. Heredity 99: 125-132. DOI: 10.1038/sj.hdy.6801001

Erdogan V., Mehlenbacher S.A., 2000. Interspecific hybridization in hazelnut. Journal of the American Society for Horticultural Science 125(4): 489-497. DOI: 10.21273/JASHS.125.4.489

Erdogan V., Mehlenbacher S.A., 2000a. Phylogenetic relationships of Corylus species (Betulaceae) based on nuclear ribosomal DNA ITS region and chloroplast matK gene sequences. Systematic Botany 25(4): 727-737. DOI: $10.2307 / 2666730$

Evanno G., Regnaut S., Goudet J., 2005. Detecting the number of clusters of individuals using the software STRUCTURE: a simulation study. Molecular Ecology 14(8): 2611-2620. DOI: 10.1111/j.1365294X.2005.02553.x

Fitschen J., 1994. Gehölzflora Ein Buch zum Bestimmen der in Mitteleuropa wildwachsenden und angepflanzten Bäume und Sträucher [Woody flora. A book for determining wild growing and planted trees and shrubs in Central Europe]. 10. Aufl. Heidelberg, Wiesbaden: Quelle \& Meyer Verlag.

Gellatly J.U., 1966. Tree hazels and their improved hybrids. Annual Report of the Northern Nut Growers Association 57: 98-101

Gürcan K., Mehlenbacher SA., 2010a. Transferability of microsatellite markers in the Betulaceae. Journal of the American Society for Horticultural Science 135 (2): 159-173. DOI: 10.21273/JASHS.135.2.159

Gürcan K., Mehlenbacher SA., 2010b. Development of microsatellite marker loci for European hazelnut ( $\mathrm{Co}$ rylus avellana L.) from ISSR fragments. Molecular Breeding 26 (3): 551-559. DOI: 10.1007/s11032-0109464-7

Gürcan K., Mehlenbacher SA., Botta R., Boccacci P. 2010. Development, characterization, segregation, and mapping of microsatellite markers for european hazelnut (Corylus avellana L.) from enriched genomic libraries 
and usefulness in genetic diversity studies. Tree Genetics and Genomes 6 (4): 513-531. DOI: 10.1007/s11295010-0269-y

Huntley B., 1990. European vegetation history: paleovegetation maps from pollen data-13000 yr BP to present. Journal of Quaternary Science 5(2):103-122. DOI: 10.1002/jqs.3390050203

Huntley B., Birks HJB., 1983. An atlas of past and present pollen maps for Europe: 0-13000 years ago. Cambridge University Press, Cambridge.

Jahn E., 1930. Bemerkenswerte Gehölze im Botanischen Garten der Forstlichen Hochschule in Hann [Remarkable shrubs in the botanical garden of the forestry high school in Hann. Münden]. Mitteilungen der Deutschen Dendrologischen Gesellschaft 42: 42-45.

Kalinowski ST., Taper ML., Marshall TC., 2007. Revising how the computer program CERVUS accommodates genotyping error increases success in paternity assignment. Molecular Ecology 16: 1099-1106. DOI: 10.1111/j.1365-294X.2007.03089.x

Kasapligil B., 1963. Corylus colurna and its varieties. California Horticultural Society Journal 24: 95-104

Kasapligil B., 1964. A contribution to the histotaxonomy of Corylus (Betulaceae). Adansonia 4(1): 43-90

Kulju KKM., Pekkinen M., Varvio S., 2004. Twenty-three microsatellite primer pairs for Betula pendula (Betulaceae). Molecular Ecology Notes 4: 471-473. DOI: 10.1111/j.1471-8286.2004.00704.x

Leinemann L., Steiner W., Hosius B., Kuchma O., Arenhövel W., Fussi B., Haase B., Kätzel R., Rogge M., Finkeldey R., 2013. Genetic variation of chloroplast and nuclear markers in natural populations of hazelnut ( $\mathrm{Co}$ rylus avellana L.) in Germany. Plant Systematics and Evolution 299: 369-378. DOI: 10.1007/s00606-0120727-0

Mitchell A., 1979. Die Wald- und Parkbäume Europas. Ein Bestimmungsbuch [Forest and park trees of Europe. A field guide]. 2. Aufl., Paul Parey, Berlin, Hamburg.

Oliveira EJ., Pádua JG., Zucchi MI., Vencovsky R., Vieira MLC., 2006. Origin, evolution and genome distribution of microsatellites. Genetics and Molecular Biology 29 (2): 294-307. DOI: 10.1590/S141547572006000200018

Palmé A., Vendramin GG., 2002. Chloroplast DNA variation, postglacial recolonisation and hybridisation in hazel, Corylus avellana. Molecular Ecology 9: 17691780. DOI: 10.1046/j.1365-294X.2002.01581.x

Peakall R., Smouse PE., 2012. GenAlEx 6.5: genetic analysis in Excel. Population genetic software for teaching and research-an update. Bioinformatics 28: 2537-2539. DOI: 10.1093/bioinformatics/bts460

Pierantoni L., Cho KH., Shin IS., Chiodini R., Tartarini S., Dondini L., Kang SJ., Sansavini S., 2004. Characterisation and transferability of apple SSRs to two European pear F1 populations. Theoretical and Applied Genetics (2004) 109: 1519. DOI: 10.1007/s00122-004-1775-9

Pritchard JK., Stephens M., Donelly PJ., 2000. Inference of population structure using multilocus genotype data. Genetics 155: 945-959

Richter E.,2013. Baumhasel - anbauwürdig in Mitteleuro- pa? [Turkish hazel - worth growing in Central Europe?] AFZ-DerWald 5: 7-9.

Schmidt PA., 2003. Bäume und Sträucher Baumhasel Kaukasiens Teil II: Laubgehölze der Familien Aceraceae (Ahorngewächse) bis Cornaceae (Hartriegelgewächse) [Trees and shrubs from Caucasus Part II: Deciduous trees of the Aceraceae families (Maple Family) to Cornaceae (Dogwood Family).]. Mitteilungen der Deutschen Dendrologischen Gesellschaft 88: 77100.

Šeho M., Huber G., Fussi B., 2017. Suitability for cultivation of provenances of Cedar and Turkish Hazel in Germany as a result of climate change. IUFRO 125th Anniversary Congress, 18-22 September 2017, Freiburg, Germany. Book of abstracts, pp. 360.

Šeho M., Huber G., 2018b. Baumhasel - Bewertung möglicher Saatguterntebestände [Turkish hazel- Evaluation of potential seed harvesting stands]. AFZ-DerWald 4: 31-35.

Šeho, M., Ayan, S., Huber, G. \& Kahveci, G. (2019). A review on Turkish Hazel (Corylus colurna L.): A promising tree species for future assisted migration attempts. South-East European Forestry 10(1): 53-63. DOI: 10.15177/seefor.19-04

Steinkellner H., Fluch S., Turetschek E., Lexer C., Streiff R., Kremer A., Burg K., Glössl J., 1997. Identification and characterization of (GA/CT) n-microsatellite loci from Quercus petraea. Plant Molecular Biology 33 (6): 1093-1096. DOI: 10.1023/A:1005736722794

Temel F., Arslan M., Çakar D., 2017. Status of natural Turkish hazel (Corylus colurna L.) populations in Turkey. Journal of Forestry Faculty 18(1): 19. DOI: 10.17474/artvinofd.270346

Truong C., Palm A E., Felber F., Naciri-Graven Y., 2004. Isolation and characterization of microsatellite markers in the tetraploid birch, Betula pubescens ssp. Tortuosa. Molecular Ecology Notes 5 (1): 96-98. DOI: 10.1111/j.1471-8286.2004.00848.x

Van Oosterhout C., Hutchinson WF., Wills DPM., Shipley P., 2004. Micro-checker: software for identifying and correcting genotyping errors in microsatellite data. Molecular Ecology Notes 4: 535-538. DOI: 10.1111/j.14718286.2004.00684.x

Wang ML., Barkley NA., Jenkins TM., 2009. Microsatellite markers in plants and insects. Part I: Applications of biotechnology. Genes, Genomes and Genomics 3 (1): 54-67.

\section{Supporting information}

Supp. Info. 1. Graphic representation of the rate of change for each $\mathrm{K}$ value. Delta $\mathrm{K}$ calculated by the Evanno et al. (2005) method. The maximum value was observed at $\mathrm{K}=2$. The second most likely clustering structure was observed at $\mathrm{K}=3$. 